SOCIAL RESEARCH REPORTS

ISSN: 2066-6861 (print), ISSN: 2067-5941 (electronic)

\title{
SOCIAL RESPONSIBILITY AND INDIVIDUAL SECURITY
}

\section{Tiberiu ILIE}

Social Research Reports, 2019, Vol. 11, Issue 3, pp. 166-181

The online version of this article can be found at:

www. researchreports.ro

https://doi.org/10.33788/srr11.3.12

Published by:

Expert Projects Publishing House

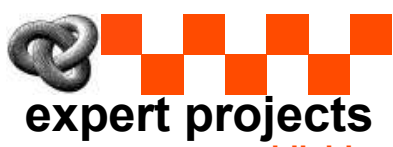

publishing

Covered by Index Copernicus International www.indexcopernicus.com

Directory of Open Access Journals www.doaj.org

On behalf of:

Center for Program and Social Development

Aditional services and information about Social Research Reports can be found at: www.researchreports.ro 


\title{
SOCIAL RESPONSIBILITY AND INDIVIDUAL SECURITY
}

\author{
Tiberiu ILIE ${ }^{1}$
}

\begin{abstract}
This paper aims to analyze social responsibility in relation to individual security. Social responsibility contains the mechanisms by which individuals and groups contribute to a collective security when the state institutions specialized intervention is not required. In this context, we will analyze the importance of responsibility for building social protection. The study is a qualitative one. The results highlight that the social responsibility of citizens can be a factor of stability, generator of security and human development. The conclusions highlight, among others, the fact that people interested in their own security are trying to find solutions for preserving the standard of living on the basis of social responsibility.
\end{abstract}

Keywords: social responsibility, individual security, social construct, human security, social representations

\section{Introduction}

In this paper, we will refer to social responsibility of the individual as a marker concerning the possibility of individuals to develop social abilities. We start from the premise that responsibility is a human trait which, along with other similar features such as temperance, conscientiousness, discernment or generosity, is an individual attribute that can be cultivated and used at the social level. We have chosen this feature because it has both personal and social connotations, is often used in the context of human security research and involves understanding personal, community and national approaches in individual security.

Alexandru Ioan Cuza University from Iasi, Iasi, ROMANIA. E-mail: ilie_tib@yahoo.com 


\section{Human, personal and individual security}

As we mentioned in a previous paper (Ilie, 2019: 118-120) it is appropriate to specify the valences of individual security concept of, individualizing it from the concepts of human security and personal security. These notions are social representations integrated in "social and ideological contexts and they can only be conceived within a social dynamic" (Fedor, 2015, 45). So, In the sense intended by Axworthy $(1999,334)$, human security means "protecting people against threats, either violence-accompanied or not; it involves preventive measures of diminishing vulnerability or reducing to minimum the risks and, in case the preventive measures are not sufficient, other measures shall be taken in order to remedy the situation". Subsequently, Van Ginkel (2000) elaborated a different approach of human security, based on the necessity to respect human dignity above all. Nevertheless, the threats against human security identified by the two researchers (fear, ignorance, poverty, famine, social and educational degradation), do not fully reveal the whole spectre of dangers and insecurity sources, which needs to be completed with environment or political-community dangers. The concept of human security "developed in close relation with the fundamental human rights, freedoms, abilities or needs which make up the vital nucleus of humans", referring to three dimensions: survival-related, living means-related and minimal dignity-related" (Alkire, 2003, 17). In addition, another analysis perspective "places human security in a relation of complementarity with human developments and human rights" (Sen, 2003, 2), and when talking about rights, we cannot miss out the corresponding obligations, which lead to another characteristic of human security, namely, responsibility.

The most recent studies on human security attempts at balancing the individual centred research. Cudworth and Hobden $(2017,2)$ argue that the "post-human turn in philosophy, ethics and social theory redefines the way in which we understand security. Through radical de-centring of humans as the only «basis» of security and ethics, it denies the anthropological fundamentals of traditional and critical security studies." Even if from a post-modern perspective, the "affiliation of an individual to a community is a constant developing social construct" (Fedor, 2014, $71)$, the individual and group security are intertwined. In the sense intended by Pigui, personal security $(2004,3)$ involves strictly individual indicators, such as "physical violence, domestic violence, child abuse, sex-related issues, human dignity, drugs etc". Pirnea $(2005,24)$ claims that "individual security refers to life, health, status, material situation or freedom of individuals, while the threat of reference can take the shape of danger, doubt or of other potential threats against the objects of reference". As Moise $(2006,2)$ said, "when talking about individual security, we must take into consideration the fact that most of the threats against individuals originate in the environment they live and get to be materialised in peer, economic or political pressure". For example, even if manifested in a variety of forms, social threats can be classified in four types: physical threat, expressed by pain or wounding, economic threats, which can materialise by limiting the access to work and resources or rights threat, which involves violating the basic human rights and freedoms and threats against the social position or human status, 
which means altering his dignity and honour by public humiliation, disregard or discrediting".

The concept of social welfare that shall be used in this paper is situated at the border of human security (seen as individual security assured by the state and institutions) and personal security (seen strictly from the point of view of the person). Hence, in the sense intended by us, individual security represents the social actions that the individual carries out in order to ensure his own safety and a decent standard of living, provided that his rights and freedoms are respected by the members of the community and state institutions, in the context of his social responsibility, which involves ensuring the safety of the other members of the society. Basically, it is the safety that the individual ensures to himself by his own means, supported by the society and community members. In this sense, the safety of the individual can be interpreted as a social capital form, a prolific concept for sociological analysis (Fedor, 2019).

\section{The concept of social responsibility of the individual}

Most of the analyses of the concept of social responsibility address businesses and companies, with the focus on the term corporate social responsibility. Without going into detail, we will point out that "corporate social responsibility is a way of sustainable development through which companies choose to treat environmental and social issues as integral parts of business operations" (Hristea, 2011, 57). On the other hand, the concept of social responsibility of the individual has been sketched since antiquity. Thus, Aristotle $(2014,67)$ said that "we punish someone for his ignorance if we consider him responsible for it", which implies that being socially responsible means not being ignorant of what is around you. Social responsibility can be defined briefly as "knowing and doing what is expected of me". In terms of rights and liberties, "individual social responsibility is a characteristic of a society in which individuals know their rights and responsibilities and act for the good of the group and in the spirit of personal independence" (Babutau, 2014, 2). These characteristics are also encountered in the legal dimension of individual security, where it is emphasized that the individual must be aware of both his duties and responsibilities. Even if the term of responsibility was established in the legal field, where it was indissolubly linked to the observance of laws and the resulting liability, it gradually expanded to group, community and societal level. Thus, "the objective responsibility ( «I am indeed the author of the act and its consequences») is willingly transformed into moral responsibility ( $« \mathrm{I}$ am the free author and this cannot be without consequences»)" (Laurent, 2012: 3).

Responsibility for our own person and for those around us is, in our opinion, a consequence of socialization, but also of the need for security, which has led to human adaptations to environmental conditions. The interpretation of the data around us, the maps of their realities and interpretation have led to the emergence of personal manifestations: "there are a series of behaviours that define the socially responsible individual: the manifestation of trust and loyalty to others; interest and sensitivity to the needs of the group/society; sense of responsibility towards problems with general social impact; positive and constructive participation 
in community life; opening up to cooperation/negotiation; manifestation of community sense, especially solidarity manifested in actions of public interest" (Babutau, 2014: 2). All these "social qualities" determine us to respect the others. "Individual responsibility is a negative respect for the freedom of others because it involves controlling its own freedom in order not to restrict the freedom of others. This is because social responsibility involves actions or inactions that guarantee political values. According to this, it is not enough to be individually responsible, but also socially responsible in order to ensure respect for freedom and social equality" (Bérubé, 2007, 73).

"There are also other interpretations of social responsibility, seen in consonance with freedom: «Modern man is particularly afraid of his own freedom». He is afraid of his responsibilities, which seem increasingly disproportionate to him, while observing the degradation of his environment, the poverty of the underdeveloped countries, or the concessions that his commitment (social) imposes on him. Consequently, the modern man does not want to be an adult, because being an adult making concessions and these are difficult to bear. Yet, today's society responds to this fear, says Pascal Bruckner. It says that it is possible to be a child forever. It is enough for the individual to focus on himself, to work enough in order to have everything he wants and wait for the state to respond to the other needs. By means of consumerism, the society provides us with all the toys we dreamed of and if we do not get what we want or if we suffer the pain of life, we can always play the victims (Bérubé, 2007, 80).

Beyond these specifications, we note that, as a result of fear, necessity or adaptation, the individual and societal security environment requires attention, involvement, and responsibility of individuals. Their responsibility, be it individual or social, contributes to the progress, development and functioning of the social parameters at peak efficiency.

\section{Methodology}

Our research is a qualitative study. The field research was carried out between March and November 2017. The target group of the study was made up of adults aged between 30 and 71 years old, with experience in the researched field (one of the dimensions of security), without limiting ourselves to the strict analysis of the concerned field (the questions addressed the fields of interest for all the respondents). We conducted 24 interviews. The body of data collected by individual interview and analysis of media materials was subjected to coding operations, according to importance and recurrence, in order to work out the categories and themes. We intend to reveal the hidden meanings of the analysed messages, based on the Grounded Theory method (Corbin \& Strauss, 1990), a methodological approach with focus on the way in which the data and their analysis became products of symbolic interactionism. Then, concepts and themes were organised in a narrative scheme which sums up the knowledge acquired on the subjects of interest for the research, grouped in thematic axis. The pursued thematic axes consisted in: the way of reporting the individual to social responsibility, the manner of manifestation 
of social responsibility in the individual's opinion, respectively, the way in which social responsibility influences individual security.

\section{Results and discussions}

\section{The way in which the individual relates to social responsibility}

Individuals do not think about individual safety, security directly, about what it means and what they do daily in order to ensure it, but act to meet the basic requirements of the pyramid of needs (food, shelter, clothing), so they look for a job, an income, and then think about the other needs (cultural, relational). However, there is a rather instinctive concern for avoiding the places or people who do not inspire confidence, confidence that they will not cause them any harm, and the individualization of the threats over the past few years - the fact that evil can occur to anyone, generated by an isolated individual - makes individuals more aware of what is happening around them, reconfigures their social maps in terms of both spatial placement (they make sure that they are not in the wrong place) and placement in the social environment (they make sure that they are not in an inappropriate entourage). And when I say inappropriate, I notice a process of social isolation of the individual in order to reduce the risk of "mismatch".

For him to be free and responsible at the same time, the individual must ensure his security, hence that he stays socially anchored.

"The man! That's the word: responsibility! Responsible freedom. It is precisely the responsibility of freedom. That's the big challenge!" (I5)

"I teach them to be responsible, and so I teach them to be aware of the fact that they are part of a machine that stops working if one of its bears roll." (I6)

The responsible person is primarily the one who helps himself. Should the individual be responsible for the group of close people? Individualism suggests that not, yet sometimes, the difficulty of providing security requires a different approach.

"I think that first of all, everyone should do what they can do. When it comes to myself, if I need help, first I will do what I think that I can do, and then, what the close ones can do, if it depends on them, because there are probably things that do not depend on them, but on institutions or ... anyway, do not expect someone else to act. It seems logical to me to try to do what you can and not to wait for another to give you food, or to lift you up if you can get up alone. At least you try, right? If everyone stands with their hands out, there may not be enough hands to lift us all." (I8) 
"Who is the main responsible for the individual security?". First of all, the individual himself, because he knows what is best for him and then comes the group, the society by its institutions, yet the thing with friend-groups is no longer available nowadays, because you cannot know for sure who your real friends are. Therefore, these kinds of friend-groups do not work anymore, it is rather collegiality than friendship, so we can call them professional interest-groups." (I9)

Is the state responsible for what is happening? It could be no one's responsibility, because we represent the state, but we impassively wait for someone to come and act...

"We have dozens of unworked hectares of land and I simply cannot understand this. I travelled by train to Bucharest and I could hardly bear to see what is happening in our country. This is not going to be fixed by engineers or simple citizens of this country, this are the responsibilities of the Romanian state and in the end, we are the ones who lose."

Responsibility also means taking into account the opinions of others, since it leads to social responsibility.

"There are people who I find difficult to communicate with and this is either because of their personal education, which limits their communication skills, but this does not mean that they do not have anything to say or they do not want to. Then, you automatically have to adjust to their level, to understand what their field of communication is and when they are opened to do it, because otherwise any try is worthless". (I13)

Disangagement and isolation are viewed as the opposite of social responsibility and even if they do not always imply running away from responsibility, they could represent the need for privacy security.

“My feedback is that sometimes, when I am too busy or assaulted with everyday's responsibilities, I choose to izolate myself from the rest, although I do not know if this is really relevant in my case.

Responsibility, including the social one, is learned since childhood, by getting to know especially the obligations derived from other's rights.

"First of all, the individual has to know what are his rights and responsibilities. Only when he knows them well, he becomes able to act. An example is even the ordinary advertisement that informs me that if I buy a TV or something else, I have the right to get it fixed in case of damages. So, if I know my rights, I can demand them but so it happens with the obligations that I have to fulfill. In this context, education is really important; for example, when my daughter comes home and tells me that I can not beat her because I do not have this right. Alright, I bought her the Constitution for children and she started to learn what out rights and obligations are and what Constitution is and finally, the children's rights. We, as parents, must do this because the school does not." (I14) 
Our exteriorly motivated urges teach us that the individual must feel good, must be free, must learn to integrate into the society. From this point of view, the responsibility seems to be in the hands of some sort of "sentenced to freedom" people who have to feel comfortable, so we can call it a self-imposed freedom.

"First of all, for an individual to be able to communicate, to get to know the rules acording to which the society works - it is not chaotic, as we may think, but wellstructured -, the rights he has, he has to learn from his early years of education that within a society, there must be an integration element, because the rights and freedoms can be rebuild and improved and I believe that they should be based on certain rules. The individual has to know that his freedom depends on the community he is part of, hence assimilating a range of rules must not determine the individual into taking an opposite stand on society, but a constructive one. He cannot live outside society, he must be part of it. This is how he expresses himself, his freedom, he can only feel good within the society, by accepting the rules of conduct of the society and individuals that he interacts with. All comes from education, since by education, the individual becomes ready to face the society in which he is going to develop and express himself. (I16)

All the dimensions of individual security are reflected in the effort of social integration by responsibility dissemination.

"For someone to feel safe, he has to give his best to obey the rules (laws), to respect the others, (education), to mind his own business (financially), to help offer his help when needed (social protection), everything for his safety, because he will be rewarded some way or another (health, ethnicity). The unconditional help that an individual provides, also creates another image of himself, since by keeping yourself safe, you get the other on your side. That is why it is very difficult to feel safe in another environment." (I17)

Social responsibility is built step by step by putting together the internal demands and the external ones: care for yourself, for your family, for the ones you love, for the members of the society and the reversal of these.

"Everybody must benefit from his rights and responsibilities. When it comes to responsibilities, for me, the main one was to take care of my children. Then, I had to assume to responsabilities when working, when interacting with my colleagues...". (I18)

Does accountability result from inertia? Is there a mutual "contamination" of individuals when it comes to responsibilities? There are lots of models, but there are also situations when the final impression is that imitating the positive actions does not have the desired effect and this is only because the individual can feel straight away the benefical effects of disseminated social accountability.

"By everything I did, I tried to attract people on my side, every single time and as many as I could. But I never thought that if by protecting myself, it could be possible to protect others too. Generally, I was tempted to believe in the idea of inertia, beacause in the moment you decide to take a certain path and show the others that the world 
can work better, then you create inertia. Unfortunately, the experience of the past years tells me that inertia does not actually work, it is exactly real." (I19)

Acting for you and for the others around you means being responsible by getting involved.

"The word responsible means a lot of things. To be responsible means to get up at 7 o'clock in the morning, to take care of yourself, of your job, of the ones around you and take responsiblity for everything you do. " (I20)

Taking care of yourself seems to be opposite to the idea of renouncement in the favour of the other, yet it is the basis of social responsibility carried out by diminishing your own security.

"I think that a responsible person has to be very careful in everything he does, he has to take into consideration what impact his actions will have on the others. A responsible person does not do anything to hurt the others. Personally, I think that first of all, one should take care of the others and then of himself. What has recently shocked me was that a young man who did an inexcusable mistake started to blame society for it by saying that it was not good enough, but the mistake was his and he overlooked it. Usually, the really responsible ones lack the instinct of self-preservation." (I21)

There are also opinions according to which responsibility for oneself implies having some qualities and taking some actions without which you cannot be responsible, especially for the others.

"Being responsible means having a strict routine, a motivation, certain principles and values, otherwise you cannot call yourself a responsible person. It is very important to be responsible for yourself and then for the others. Here, things become contradictory sometimes, because if you cannot be responsible for yourself, then it is unlikely that you will be responsible for the others. (I22)

"Let us be aware of the fact that our actions may have an impact not only on one individual, but also on a greater community and thus, one should take responsibility for his action. It is important to understand that what you are doing may have a negative impact and one must be aware of this when making a decision. This also means to act responsibly: to be aware of your actions and their results." (I23)

The way in which social responsibility manifests in the view of the individual

Social responsibility is also seen as an internal impetus, as well as external pressure, but also sometimes as an attempt to bypass all this, to diminish social involvement and to increase the area of personal rights. When accountability is done through external imposition, it yields results if it is considered appropriate and educative. 
"But they have to be aware that they are responsible for doing something. So they must be aware, not that it is a joke or a play, but we laugh a lot, but then, because when work must be carried out, everybody must pay attention!" (I6)

If accountability is made from within, the expectations must be adjusted in an educational direction as well.

"I think I am involved enough, and one needs to know how to adjust themselves to expectations with which they are satisfied at some point. So, you can say you want the moon from the sky, and you will be frustrated all your life, but you have to understand that there are certain limits you can reach and others that you cannot. And you have to learn to live with what you have and what you can get." (I8)

There are also situations in which the individual fights an internal battle to reduce external accountability, and the solution to this dysfunction is also found in education.

"It is a natural tendency for the individual to ignore his obligations. And then I think that more needs to be done for this, awareness must be realized, because from what I have seen in practice (because I work with contracts), the reading of the part of the obligations is skipped, it is avoided. And the best example can be found in banks: most of those signing contracts with banks do it by knowing they have nothing to change and negotiate. The individual skips some of the obligations he is likely to face later, and this is why I think that educating people about the awareness of the rights and obligations he has, must start in school, but we do not teach law in schools, so we do not teach the essential subject matter individuals face in society. Wherever you go, you encounter issues of morality, ethics, it is true that certain aspects of morality and ethics are taught during the religion class in schools, yet not all parents allow their children to participate in this class." (I10)

Making social responsibility an objective for the individual gets reflected in the way we respect the others, which leads to the conclusion that responsibility is a personal construct validated by the social environment.

"You gain respect from people in any way or you do not, you will eventually not enjoy it anyway. And that is what I noticed in my years of rest. Whoever respected me and was with me remained, whoever did not respect me and was not with me is not even now, although they only return aesthetically in my life, as a presence and asks to meet me for a beer, a cognac, a coffee, a football match, a public event, anything else just to look for my proximity again. Obviously, they want something in return, but it rather demotes me and induces me a kind of rejection, even social, of that person rather than approaching him or her." (I13) 
Information is seen as the basis for individual responsibility.

"People prefer to give their opinion rather than going and convincing by themselves. If you tell them that two cars have collided, they all think, because it is normal, but if you say something good has happened, they are sceptical. Someone told me once that it is very difficult to prove that you are an honest man. The fact that you are a crook, a thief proves itself." (I13)

Socialization, as a form of social responsibility, appears in the individual's construct about his actions and the ones of people around him, but he appreciates that the level of socialization is lower; the individual feels the need for loneliness, isolation (as I said above, isolation from inappropriate places or people).

"However, I can feel that there is a need for physical closeness. I noticed it in the West in the same way at the adult level. Many people consider physical approach libidinal or false, but some hug each other, say hello to each other on the street, kiss three times on the cheek and not twice, and say hello to each other even if they do not know each other. I feel like many want to be with others, but they feel much better alone. They talk, meet an hour or two, and then feel the need to be alone in their own world. The question is why is this happening? As far as I am concerned, when I came from school, I was looking forward to meeting my friends ...” (I13)

Taking into account the human tendency to avoid obligations, the individual believes that responsibility can only be imposed, which does not always have the expected results, as it increases the resistance to change of the individual forced to be responsible.

"Do you know what it is like? You teach people about the rights they have, but they often forget they have obligations too, you know? This happens many times. You have rights, but you also have some obligations, yet you never mention them. Someone will not come to say, look, I have an obligation ... no, sir, I have the right to ... That is how it happens in the social protection area, there are only rights. Sometimes, their obligations, which they do not want to fulfil, involve community service, namely, cleaning up some places in the city, although I do not always consider this activity useful, make the ones from the areas where others clean up to be accustomed to not meeting their obligations of keeping the area clean, because they know that sociallyassisted people come to clean it up for them. I am thus generating a non-adaptive behavioural pattern. On the other hand, you cannot even let the socially-assisted individual without doing anything. Let them go to work, most of them clean up the yards of public institutions." (I14)

Social responsibility is also seen as the process of learning and using personal skills for societal purposes.

"And there is a problem in making other people appreciates your work, determining them to work for society, because in the end, this is a partnership. I believe that social security generally comes from the feeling of the individual towards society. It depends on how he is educated, what decency and a decent life means to him. Society needs 
to impose the teaching of entrepreneurial education in school, it needs to determine the individual to do something, sell, build, and cultivate certain skills that it will later capitalize if he is inclined." (I16)

"In my opinion, evolution means a common effort, made by all individuals, members of a society. And then I think it means integration, namely, being part of a team so you can make a joint effort to evolve. Every individual should do what he can, depending on his abilities." (I19)

The respondent's assertion about the achievement of the happiness of others and later his one is supported by facts, and the number of those who act or feel the same is probably greater than he thinks.

"There are few people who want to be responsible for those around them and then for them, but I want to be, to make those around me happy, and then to be happy for their happiness." (I20)

Social responsibility is seen as starting from the individual, but with the support of others.

"I think the most responsible is he, the individual, and you need the help of others. But the most responsible for your safety is you. Undoubtedly, you cannot be alone; you need the help of those you have mentioned: family, friends, and institutions. " (I21)

The motivations to be responsible for him and others are diverse, one of which being of a religious nature.

"As a religious person, I observe the commandment "Love your neighbour as yourself». If you do not love yourself, you cannot love others. I see social responsibility this way: as long as I am responsible for myself and for my actions, I cannot harm other people, but on the contrary, I think that through the activity that I carry out, through my responsibility, I must not invade someone's space or hurt anyone, maybe even help, if I can. "(I22)

Being socially responsible simply means the awareness of others' existence.

"Let us be aware that our daily activity has an influence on individuals in general and on society." (I23)

\section{The way in which social security influences individual security}

There is a relationship of mutual, socially mediated, influence, between the individual and responsibility. Social influences are not always seen as beneficial, and dialogue and negotiation being required. The individual feels insecure, permanently insecure, is "attacked" from everywhere, and then he feels the need for help, knowing that he will receive it if he does something, anything. This implies social responsibility: conscious security through participation, dialogue, 
respect, self-awareness. Social responsibility is manifested within a group and can have an individual educational effect.

"When a rule is not obeyed, the one who breaks it must be put in his place, and everyone is very pleased. Everyone unites against a vice." (I6)

Lack of engagement, responsibility, assumption, makes us more insecure, and this insecurity seems to make us even less responsible and hence we expect others to take the first step.

"Rights and freedoms are in balance with responsibility ... I find it natural, I have the right but I forget to mention my obligations. I also have obligations, I admit, I want the state to secure my job, I want roads, it is normal, I know that it is not always the right thing to do, the funds are being siphoned off and so resources are lacking, but at the same time, I also have a responsibility, sometimes I show it, sometimes I do not. But I am revolted." (I11)

If social responsibility is seen in relation to education, then everything affecting education also affects social involvement. In this case, the media and the negative message it transmits are seen as responsible for irresponsibility.

"I think that in Romania, media promotes a reality that is rather negative, sad, bleak, I do not know why, but the effect is obvious and unfortunately, it seems to create addiction, because people actually stand and absorb that news. If you ask them to look at an educational or culinary show, they do not pursue it with the same interest, and then I wonder if it is not wrong somewhere or something is desired, but you just want to sell your piece of news?" (I13)

The negative message of media is even seen as a wilful act of insecurity, which affects the act and the social role of responsibility.

"Maybe it would be interesting to study the extent to which the media propagates this negativism that becomes and creates addiction, becomes an attention absorber. And I wonder what the purpose is, is it that you want to generate pessimism? For this finds expression in the act of life." (I13)

The individual is often left alone in the midst of social messages that trouble him, being tempted or determined to opt for an association with view that does not characterize him but gives him a sense of security.

"I want to say that it is very difficult nowadays to discern between and to quantify what is good and what is bad, because everything has a certain connotation, everything is associated with something, and I notice that people are very much biased, they practice social blame and have many social stereotypes." (I13)

When the responsibilities of those people around do not live up to your expectations and when personal responsibility fails to give a chance to socialization and communication, the individual withdraws from the social environment and 
sends a strong message by which he rejects reality, the surrounding world, to the detriment of a dream, of a chimera.

"I saw a message sent on the networks that they were talking about and I was shocked by the fact that they prefer the virtual world to the real world because the real world is ugly and I do not feel good in it, while there (in the virtual world) I can create it as I want it." (I13)

Information is seen as very important in making individual decisions, but also as a basis for the accountability of the individual or those people around, especially when it comes to individual and collective security.

"In my opinion, our generation is starting to do something, because from my point of view, the generation of my parents still showed respect for the white collars, namely, they were doing what they were saying. Hence, you respect someone for the position he has and for which he has probably prepared and learned a lot, but take a moment to reconsider the fact that we start to have access to all kinds of information and news, we have the right to be informed, guided, advised, yet we are the ones making the decisions and so we no longer accept anything imposed on us. As far as vaccination is concerned, for example, I had to give a self-declaration saying that I did not vaccinate my baby. Theoretically, it only concerns yourself if you want to go to a doctor and take care of your health or not. Gradually, the issue is no longer raised in the same way and if you do not care about your health, you may affect others too. But these decisions must be taken after consultation, because there are associations of parents of children with autism who claim that a certain type of vaccine is not good. Does anyone ask them for anything? Let us listen to their opinion as well. There are more interests and more rights involved here: those of the individual, those of the community or the state. It is hard to decide, yet dialogue is important." (I14)

Social responsibility means protecting a person who respects norms, values, the social environment, or to put it differently, social responsibility means ensuring individual security by taking social action.

"I think the most important thing for a person is the civic attitude and power of the example. One cannot do this by himself; he needs the help of the society. Normally, society sets some rules, and those rules must be protected. Generally, institutions are created to defend those norms and when a rule is violated, it affects him directly and in this situations, he should be automatically defended by the institutions that are empowered to take actions in this direction. Usually, as long as there are institutions of justice in a society, it is not appropriate for the individual to take the law into his own hands, because that is why institutions have been created - to protect the norms that collective groups have established; we call them values, since we expect to receive protection." (I16) 
The main resort of responsibility, social action and security is found in the individual who wants, can and does.

"Wanting is not enough. What you do for the thing you want is very important. It is good that one wants, but he accumulates frustration because he does nothing to acquire that. And he says: I cannot do it! But what did he do to succeed? So in the end, it must be a competition with ourselves if we want to achieve something." (I16)

Responsibilities can sometimes be a burden for the individual, therefore it is appreciated that self-knowledge and delimitation of some goals, together with others, would be necessary.

"The individual should begin by bringing order to his ideas, to his vision, to his priorities, to his self-analysis as a human being. Then, family, workplace, colleagues, everybody plays a very important role. Maybe most people should do some courses in order to understand them, because many people do not know that they are wrong, many do not know what they are doing or what they will do tomorrow, it is a chaotic and quick analysis, without structure and foundation, it is basically an explosion that also causes a small panic around it." (I20)

Personal security is seen in the context of social relationships and can be become a means of defence on condition that the links are initiated by the individual.

"First, every individual is responsible for himself. Certainly, since our development also depends on the people around us, it is important to receive the support, the agreement, the help of the people around us, and then all this is a complex of links that are being created. There are studies showing that relationship with family, with people in society helps a lot in our physical, mental security, but it is very important for people to make a step towards building this relationship. As individuals, we are the main pawn, and from this position we have social connections and the more they are, the more peaceful and secure we feel, the more positive we think, the more we manage to overcome certain problems, because we are supported both individually and socially." (I22)

The engine of responsibility is seen in the individual, the only one able to decide action or inaction.

"We all have the same responsibility, from individuals to state institutions, each in his area of action. As long as responsibility does not start from the individual, you do not want the state or the community to intervene, because the rejection effect may appear, and this leads to cases of juvenile delinquency, for example. So it has to start from the individual." (I23)

There are also complementary opinions, which identify the motivation mechanisms in institutions by informing the individuals, later generating responsibility. 
"I think the state institutions are primarily responsible for the security of the individual; we intersect daily with a lot of institutions that are vital to human life and it is necessary for the individual to be informed with absolutely everything he needs and to assimilate, to be open to it. You cannot expect him to be informed without offering him the means to be so. Where does he get his information from? It would be more convenient for people to be informed, to be told what to do." (I24)

\section{Conclusion}

Respondents are aware of the fact that an individual's responsibility, but especially social responsibility, are issues they have not thought seriously about; when they prove responsible for themselves and for others, they make it in an inert manner, as an obligation, because of reciprocity, yet it is necessary and desirable to manifest it in its fullness, not just from time to time. The answers to interviews have shown that there was no fear of the individual as a result of violent acts of terrorist attacks, but rather of the violence of isolated individuals, marked by momentary problems, considered unresponsive. However, an isolated person causes individuals to be more alert to what is happening around them, to the social responsibility identified in the immediate environment. As a reaction, they constantly reconfigure and adapt virtual maps in terms of both spatial placement (they make sure that they are not in the wrong place) and placement in the social environment (they make sure that they are not in an inappropriate entourage). This avoidance of mismatch brought about a process of social isolation of the individuals in order to reduce this risk.

The individual is seen by the majority of respondents as the main responsible for his security, but at the same time, he is socially placed in the common effort to assure securities, with each person's responsibility being the binder and the engine of security. Last but not least, we note the high degree of responsibility required in some situations where state institutions, through their inertia, lack of power or involvement, seem to have negative consequences on the individual's security, which has a positive effect on the awakening of social conscience and responsibility. 


\section{References}

Alkire, S. (2003). A conceptual framework for human security. Oxford: Centre for research on inequality, human security and ethnicity - CRISE.

Axworthy, L. (1999). La sécurité humaine: la sécurité des individus dans un monde en mutation. Politique étrangère, 64(2), 333-342.

Babutau, I.C. (2014). Responsabilitatea sociala a individului-voluntariat (www.carpevita. uvvg.ro).

Bérubé, F.S. (2007). Le principe responsabilité de Hans Jonas et la responsabilité sociale (www.archipel.uqam.ca).

Corbin, J., \& Strauss, A. (1990). Grounded Theory Research: Procedures, Cannons, and Evaluative Criteria. Qualitative Sociology, 13(1), pp. 3-21.

Cudworth, E., \& Hobden, S. (2017). Post-human Security. In A. Burke, R. Parker (eds), Global Insecurity (pp. 65-82). London: Palgrave Macmillan.

Fedor, C. (2014). Towards a Postmodern Approach of Ethnic Community. Postmodern Openings, 5(2), 71-80.

Fedor, C. (2015). Current Issues on Social Representations. Analele Ştiintifice ale Universitatii „Alexandru Ioan Cuza” din Iași. Sociologie şi Asistenta Sociala, $8(1), 35-46$.

Fedor, C. (2019). Social Capital and Community Development: Case Study. Social Research Reports, 11(1), 65-77.

Hristea, A.M. (2011). Responsabilitatea sociala corporativa - între deziderat şi realitate. Economie teoretica şi aplicata, vol. XVIII, 10(563), 56-73.

Ilie, T. (2019). The Role of Social Welfare in Providing Individual Security. Social Research Reports, 11(1), 117-137.

Laurent, A. (2012). Calatorie spre limita responsabilitații individuale (www.contrepoints. org).

Moise, S. (2006). Fatete ale conceptului de securitate. Revista Colocviu Strategic, 5, 1-6.

Pigui, T. (2004). Securitatea economica şi securitatea umana globala. Revista Colocviu Strategic, 8, 1-8.

Pirnea, V. (2005). Dimensiunea de securitate și aparare a Uniunii Europene. București: Editura Centrului Tehnic-Editorial al Armatei.

Sen, A. (2003). Human security now. Soka Gakkai International Quarterly.

Van Ginkel, H., Newman E. (2000). In Quest of Human Security. Japan Review of International Affairs, 14 (1), p. 59-82. 